\title{
EUROPEAN UNION MEMBER STATES PREPARING FOR EUROPE 2020. AN APPLICATION OF THE MULTIMOORA METHOD
}

\author{
Willem Karel M. Brauers ${ }^{1}$, Alvydas Baležentis ${ }^{2}$, Tomas Baležentis ${ }^{3}$
}

\author{
${ }^{1}$ Vilnius Gediminas Technical University, Lithuania and Faculty of Applied Economics, \\ University of Antwerp, Prinsstraat 13, 2000, Belgium \\ ${ }^{2}$ Mykolas Romeris University, Ateities g. 20, LT-08303 Vilnius, Lithuania \\ ${ }^{3}$ Lithuanian Institute of Agrarian Economics, V. Kudirkos g. 18, LT-03105, Vilnius \\ E-mails: ${ }^{1}$ willem.brauers@ua.ac.be (corresponding author); ${ }^{2}$ a.balezentis@gmail.com; \\ ${ }^{3}$ t.balezentis@gmail.com
}

Received 10 December 2010; accepted 02 January 2012

\begin{abstract}
It is the intention of the European Union to create a growing and sustainable European economy by 2020 , a much more moderate target than the 2010 target of becoming the most competitive and dynamic knowledge-based economy in the world. This intention has to be supported by an adequate Optimization and Decision Support System.

Therefore, MULTIMOORA is proposed. MULTIMOORA is a quantitative method, which compares multiple and optimum objectives, expressed in different units, as much as possible on a nonsubjective basis. In opposition to similar methods MULTIMOORA does not need normalization, being based on dimensionless measures. Importance of an objective can eventually be given by the stakeholders concerned. MULTIMOORA is composed of three approaches: Ratio System, Reference Point and Multiplicative Form Methods, all of the same importance and each controlling each other. Twenty two objectives, 10 originating from statistics and 12 from statistics and forecasts, important for the future, characterize the $27 \mathrm{EU}$-Countries economies as a preparation for 2020. Which of these countries are the best prepared for 2020? A Dominance Theory, summarizing the three obtained ordinal numbers per country, ranks the 27 countries for that purpose.
\end{abstract}

Keywords: multi-objective optimization, European Union, Ratio System, Reference Point Method, Full Multiplicative Form, MULTIMOORA.

Reference to this paper should be made as follows: Brauers, W. K. M.; Baležentis, A.; Baležentis, T. 2012. European Union member states preparing for EUROPE 2020. An application of the MULTIMOORA method, Technological and Economic Development of Economy 18(4): 567-587.

JEL Classification: C44, E61, F59, M2, O22. 


\section{Introduction}

The Lisbon Strategy (European Council 2000) was adopted in 2000 and focused on turning the European Union (EU) into "the most competitive and dynamic knowledge-based economy in the world" by 2010.

Today it is obvious that many goals of the Lisbon Strategy for 2010 were not met. Therefore the new strategy Europe 2020 was initiated in 2010 (European Commission 2010). The new strategy aims to the creation of a growing and sustainable European economy. Furthermore, greater policy coordination between national governments and the EU is an additional focal point of the Strategy Europe 2020.

Twenty two objectives, 10 originating from statistics and 12 from statistics and forecasts, important for the future, will characterize the 27 EU-Countries economies as a preparation for 2020. Nevertheless these data concern only the economic guidelines of Strategy Europe 2020 and not the climate and energy targets.

As all these data are expressed in different units the exercise needs an adequate Decision Support System for optimization. For the researcher in multi-objective decision support systems the choice between many methods is not very easy. Indeed numerous theories were developed since the forerunners: Condorcet (the Condorcet Paradox, against binary comparisons, 1785, LVIII), Gossen (law of decreasing marginal utility, 1853) Minkowski (Reference Point 1896, 1911) and Pareto (Pareto Optimum and Indifference Curves analysis 1906, 1927) and pioneers like Kendall (ordinal scales, since 1948), Miller and Starr (Multiplicative Form 1969), Roy et al. (ELECTRE, since 1966), Hwang and Yoon (TOPSIS 1981), Brans et al. (PROMETHEE since 1984), Saaty (AHP, since 1988) and Opricovic, Tzeng (VIKOR 2004; Fouladgar et al. 2012). Already in 1983 at least 96 methods for Multi-Objective Optimization existed (Despontin et al. 1983). Since then numerous other methods appeared. Therefore, we only cited the probably most used methods for Multi-Objective Optimization.

Twenty two objectives from 27 countries result in 594 data, which means that methods of partial aggregation can not be used. Schärlig $(1985,1996)$ gave the name of partial aggregation to: the Electre Group (Electre I, Electre Iv, Electre Is, Electre TRI, Electre II, Electre III and Electre IV) and Prométhée.

The Analytic Hierarchy Process (AHP) of Saaty (1988) uses weights. The use of weights was introduced by Churchman and Ackoff (1954) and Churchman et al. (1957). This Additive Weighting Procedure (MacCrimmon, 1968: 29-33) was called SAW, Simple Additive Weighting Method, by Hwang and Yoon (1981: 99). Weights defined in that way for using in Multi-Objective Optimization have the disadvantage to possess a double content namely normalization on the one side and giving importance on the other. In addition, for the European example, 22 weights have to be defined or 44 normalization and importance exercises.

Also the methods of partial aggregation use weights. Even more, all these methods are expert oriented with qualitative statements as a basis. As conclusion one may say that for this application preference has to be given to a method of total aggregation and a method not using weights.

The article is organized in the following way. Section 2 deals with the objectives characterizing the economies of the EU Countries for the present and for the future. Section 3 focuses on further considerations on methods for Multi-Objective Optimization. The MOORA 
method is explained in section 4 and MULTIMOORA in section 5, both methods satisfying the conditions of total aggregation and of not using weights. Section 6 describes the numerical example where the European Union States are compared on basis of structural indicators and of the new method. Finally conclusions are drawn: which of these countries are the best prepared for 2020 from the economic point of view? A Dominance Theory, summarizing the three obtained ordinal numbers per country, ranks the 27 countries for that purpose.

\section{Choice of objectives characterizing the economies of the $\mathrm{EU}$ countries in the present and in the future}

The Choice of Objectives characterizing the Economies of a Country for the Present and for the Future is restricted to the available data. Afonso et al. (2011) mention that four variables have short-run impact on ratings namely the level of GDP per capita, real GDP growth, the public debt level and the government balance. Government effectiveness, the level of external debt and external reserves are important long-run determinants.

The national economies to be studied concern the Economies of the European Union Member States. We selected twenty-two objectives, ten originating from statistics and twelve from statistics and forecasts important for the future, in order to characterize the $27 \mathrm{EU}$-Countries economies as shown in the following Table 1.

\section{No. 1, 17 and 21 Government Budget Deficit}

The IMF correlates the Government Budget Deficit to GDP for a given year and not to GNP. Let us remember that the Gross Domestic Product (GDP) is a territorial concept, the Value Added realized on the territory of a country during a certain year. On the contrary the Gross National Product (GNP) is a personal concept related to the citizens and the permanent residents of a country ${ }^{1}$. In fact the Government Budget Deficit is a part of the yearly Government Budget and rather has to be related to that budget and not to GDP, otherwise some countries are punished and others are rewarded. Indeed at the time of the EU 15 the government budget of Sweden compared to $56.6 \%$ of its GDP (Belgian Federal Department of Finance, Documentatieblad 2008, 46), which means that for instance a government deficit of $3 \%$ of GDP corresponds to a deficit of $5.3 \%$ of its government budget. At the other side Ireland with $34 \%$ government expenses compared to its GDP (Belgian Federal Department of Finance, op.cit. 46) may run a deficit of 8.8\% of its government budget. One could conclude that a country with high government expenses compared to GDP is punished in that way.

Interesting to know is that the government budget deficit is linked to the government debt. Indeed the deficit and the increase in the interest payments on the government debt determine an increase in the government debt. In this way the government debt is composed of primary expenditures and of interest payments. Consequently, the impact of the government on the government debt runs through the budget deficit and the obtained rates of interest on the government debt.

Also the Treaty of Maastricht, the starting point of the EURO, correlates the Government Budget Deficit to GDP (Belgian Federal Department of Finance, Documentatieblad 2008, 29). 
Table 1. The 22 objectives characterizing the Economies of the European Union Member States

\begin{tabular}{|c|c|c|c|c|}
\hline No. & Indicator & Period & Dimension & Optimum \\
\hline \multicolumn{5}{|c|}{ A. Actual } \\
\hline 1 & Government Budget Deficit (a) & 2010 & $\%$ of GDP & MIN \\
\hline 2 & Government Debt (a) & 2010 & $\%$ of GDP & MIN \\
\hline 3 & Current account deficit (BoP) (a) & 2010 & $\%$ of GDP & MIN \\
\hline 4 & GDP per capita in PPP (a) & 2010 & in current international dollar & MAX \\
\hline 5 & GDP growth rate (a) & 2010 & per cent of GDP of previous year & MAX \\
\hline 6 & Inflation (a) & 2010 & $\begin{array}{l}\text { per cent compared to a reference } \\
\text { period }\end{array}$ & MIN \\
\hline 7 & Government bond yields (a) & 2010 & per cent & MIN \\
\hline 8 & Employment rate (b) & 2010 & per cent of age group 15-64 & MAX \\
\hline 9 & Unemployment rate (b) & 2010 & $\begin{array}{l}\text { per cent of the professional } \\
\text { population }\end{array}$ & MIN \\
\hline 10 & Tertiary education (b) & 2010 & per cent of age group 30-34 & MAX \\
\hline \multicolumn{5}{|c|}{ B. Prospective } \\
\hline 11 & Median Age (b) & 2010 & Median of total population & MIN \\
\hline 12 & Proportion of population aged $0-14(\mathrm{~b})$ & 2010 & per cent of total population & MAX \\
\hline 13 & Proportion of population aged $15-64(\mathrm{~b})$ & 2010 & per cent of total population & MAX \\
\hline 14 & $\begin{array}{l}\text { Proportion of population aged } 65 \\
\text { and over (b) }\end{array}$ & 2010 & per cent of total population & MIN \\
\hline 15 & GDP per capita $($ EU-15 = 100) (c) & 2011 & index number with EU-15 = 100 & MAX \\
\hline 16 & GDP growth rate $(\mathrm{c})$ & 2011 & $\%$ of GDP of previous year & MAX \\
\hline 17 & Government Budget Deficit (c) & 2011 & $\%$ of GDP & MIN \\
\hline 18 & Government consolidated gross debt (c) & 2011 & $\%$ of GDP & MIN \\
\hline 19 & GDP per capita $($ EU-15 = 100) $(\mathrm{c})$ & 2012 & index number with EU-15 = 100 & MAX \\
\hline 20 & GDP growth rate $(\mathrm{c})$ & 2012 & per cent of GDP of previous year & MAX \\
\hline 21 & Government Budget Deficit (c) & 2012 & $\%$ of GDP & MIN \\
\hline 22 & Government consolidated gross debt (c) & 2012 & $\%$ of GDP & MIN \\
\hline
\end{tabular}
(a) The data come from IMF and World Bank (2011).
(b) EUROSTAT (2011).
(c) European Commission (2011).

\section{No. 2, 18 and 22 Government Debt}

The International Monetary Fund (IMF) once again relates Government Debt to Gross Domestic Product. Government Debt is distinct from the debt of the households, which depends on household expenditures and savings. In Europe the savings ratio of the households is the highest in Spain, Germany and Belgium, translated in Belgium of a participation ratio of the Belgians in their own government budget of around $46 \%$. The International Monetary Fund does not separate domestic from external financing for the government debt, though an important issue. Related to GDP Japan has one of the highest government debts of the world, probably around $200 \%$ of GDP, but mainly financed by the own population. As a consequence the interest rate on the government debt is extremely low, sometimes $1 \%$ on 10 -year govern- 
ment bonds. On the contrary Greece with a government debt of $142.8 \%$ in 2010; estimated at $157.7 \%$ in 2011 and at $166.1 \%$ in 2012, had to pay an interest rate of $13.2 \%$ in 2010 increased to $16.69 \%$ on June 11, 2011 (European Central Bank 2011). The reason is that around $71 \%$ of the Greek government debt is in the hands of foreigners, mainly foreign banks.

Once the foreign part of government debt is very high it is difficult to bring it down. Previously in Europe devaluation of the national currencies was helpful, which is impossible with the Euro, unless as a function of a basket of the main other currencies in the world, comparable to the system of drawing rights of the International Monetary Fund. Otherwise, one has to foresee international transfer payments or reduction or complete remission of the government debt in the hands of foreigners. Nevertheless, one has to question the possibility to foresee a fiscal outlook until 2035 as has been done by Gagnon (2011). Any way we stopped our forecasts until the end of 2012.

\section{No. 3 Current Account Deficit in the Balance of Payments (BoP)}

The Current Account Balance is the sum of net exports of goods, services, net income, and net current transfers. Once again the IMF correlates the Current Account Deficit in the Balance of Payments to GDP and not as a part of the total of the Current Account of the Balance of Payments for a certain period ${ }^{2}$. Nevertheless it may happen that in typical export oriented countries like the Benelux countries the total of their Current Account of the Balance of Payments is larger than their GDP.

\section{No. 4 GDP per Capita in Purchasing Power Parity (PPP)}

Purchasing Power Parity means that the GDP per country is not compared on basis of exchange rates but on basis of the consumer basket with its prices of a country compared with the consumer basket with its prices, the purchasing power, of a standard country, namely the United States. In principle the GDP per Capita in a Purchasing Power Parity (PPP) would measure the real purchasing power of the consumer in a country.

\section{No. 5, 16 and 20 GDP Growth Rate}

GDP Growth Rate represents the per cent of GDP growth compared to previous year in constant prices.

\section{No. 6 Inflation}

Inflation is expressed in averages for the year, not end-of-period data. A consumer price index (CPI) measures changes in the prices of goods and services that households consume. Such changes affect the real purchasing power of consumer income. As all the prices of different goods and services do not change at the same rate, a price index can only reflect their average movement. A price index is assigned a value compared to some reference period. Price indices can be used to measure differences in price levels between different countries at the same point in time. For Euro Countries, consumer prices are calculated based on harmonized prices.

2 Also the World Bank correlates the Current Account Deficit in the Balance of Payments to GDP (World Bank 2011). 


\section{No. 7 Government Bond Yields}

Yields of Government Bonds concern Government bond yields with maturity close to 10 years.

\section{No. 8 Employment Rate}

The Employment Rate is the rate of people employed as a percentage of the age group 15-64.

\section{No. 9 Unemployment Rate}

The Unemployment rate is the rate of people unemployed as a percentage of the professional population (people disposed to work in the age group 15-64).

\section{No. 10 Tertiary Educational Attainment}

Tertiary Educational Attainment is the rate of people who finished any form of higher education as a percentage of the age group 30-34.

\section{No. 11 Median Age}

Median Age is the median of the ages of the entire population.

\section{No. 12 Proportion of population aged 0-14}

Population aged $0-14$ is compared to total population.

\section{No. 13 Proportion of population aged 15-64}

Population aged 15-64 is compared to total population.

\section{No. 14 Proportion of population aged 65 and over}

Population aged 65 and over is compared to total population.

\section{No. 15 and 19 GDP per capita $(E U-15=100)$}

GDP per capita is a percentage compared to the GDP per capita with EU-15 = 100. In the year 2000 the European Union was composed of the original 15 member states. In 2004 the 10 new countries joined and finally in 2007 Romania and Bulgaria. In 2013 Croatia will join.

The data for the 22 objectives are given in the following Table 2.

\section{Choice of a method for multi-objective optimization}

Based on previous analysis, methods of partial aggregation and methods based on weights are excluded for large decision matrices.

How is it possible to exclude Weights? Therefore it is necessary to read the decision matrix, in the European example composed of 594 elements, not in the horizontal but in the vertical way. By making averages per column of the decision matrix dimensionless measures are obtained. 


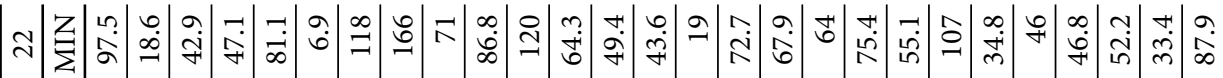

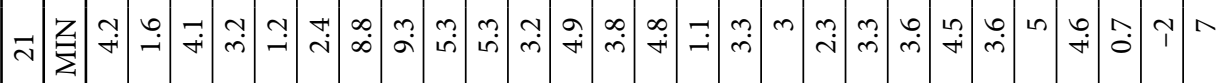

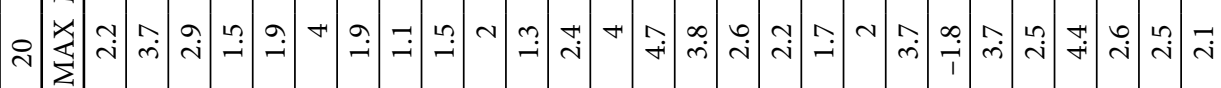

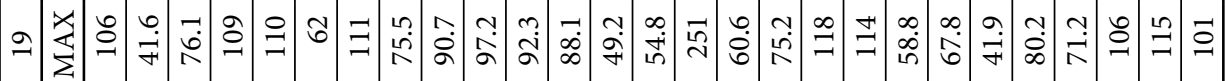

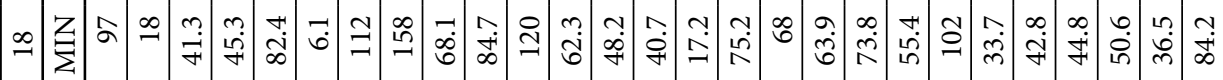

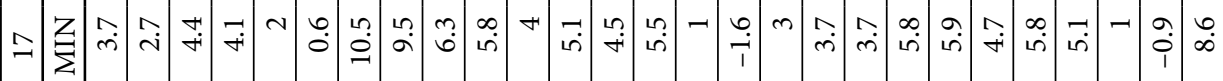

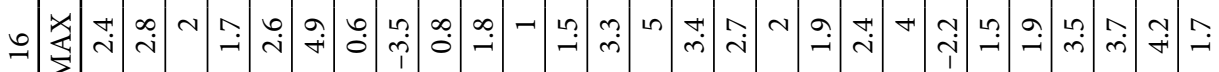
$\curvearrowleft$ 닐

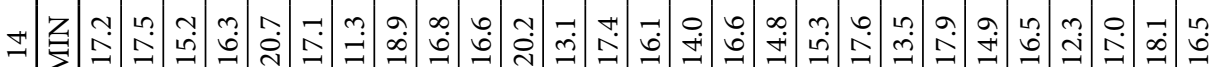

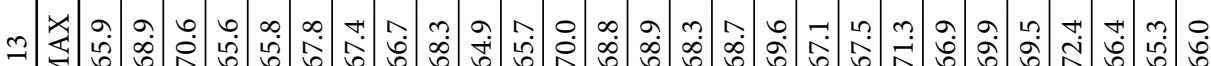

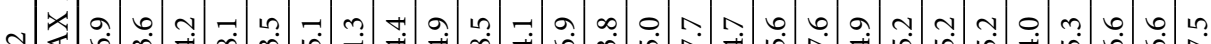

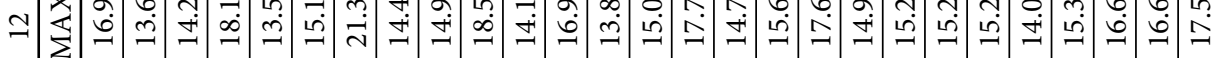

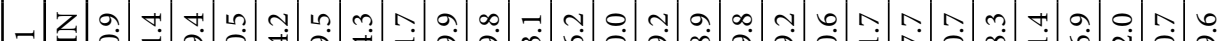

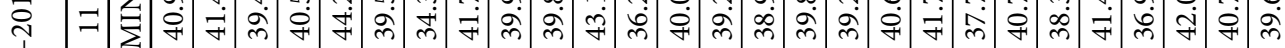
$\because$ ○

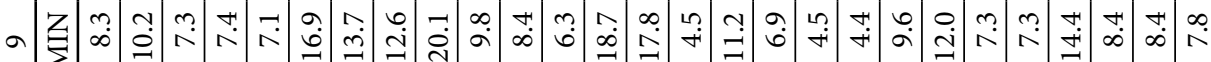

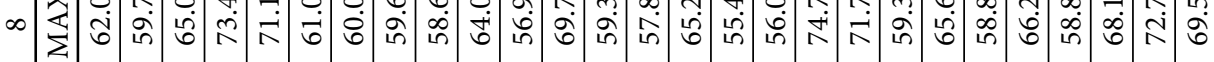

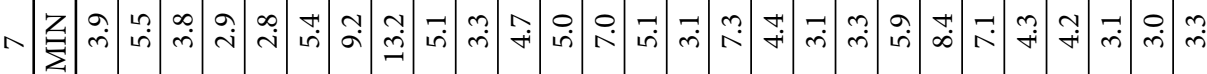

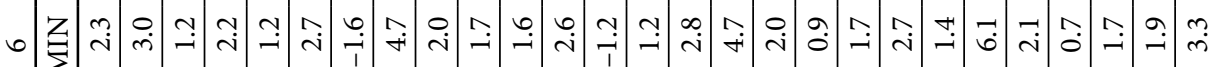
य)

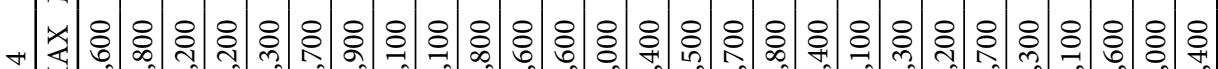

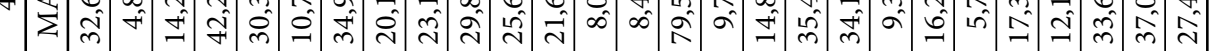

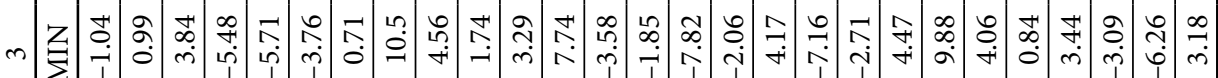

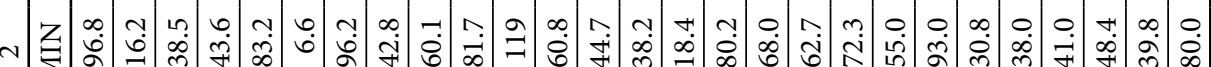

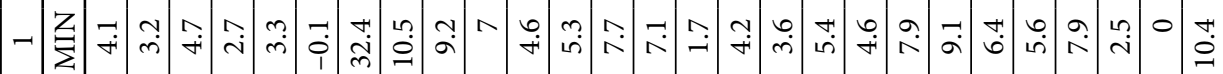


Reference Point Methods like TOPSIS (Hwang, Yoon 1981) and VIKOR (Opricovic, Tzeng 2004) do not use weights but rather dimensionless measures, but they are overtaken by MOORA which is composed of two different dimensionless based methods, each controlling each other.

Chakraborty (2011) for decision making in manufacturing compared MOORA to TOPSIS and VIKOR concerning: computational time, simplicity, mathematical calculations and stability. For all these characteristics MOORA was superior to TOPSIS and VIKOR.

Later (Brauers, Zavadskas 2010) MULTIMOORA overtook MOORA by assembling three instead of two methods and, in fact, by assembling all possible methods with dimensionless measures.

The Ratio System is the first part of MOORA. In MOORA the decision matrix is read not in the horizontal but in the vertical way. The obtained ratios are used as inputs in the Reference Point Method where they are compared with the coordinates of a Reference Point.

In order to make the series of dimensionless measures methods complete a Full Multiplicative Form is added, whereby its factors loose their identity and ipso facto become dimensionless.

\section{Multi-objective optimization by ratio analysis (MOORA)}

\subsection{The two parts of MOORA}

The method starts with a matrix of responses of different alternatives on different objectives:

$$
\left(x_{i j}\right)
$$

with: $x_{i j}$ as the response of alternative $j$ on objective $i$

$i=1,2, \ldots, n$ as the objectives.

$j=1,2, \ldots, m$ as the alternatives.

MOORA goes for a ratio system in which the response of an alternative on an objective is compared to a denominator, which is representative for all alternatives concerning that objective.

If the sum of each alternative per objective is chosen for this denominator, the traditional formula of averages is obtained:

$$
x_{i j}^{o}=\frac{x_{i j}}{\sum_{j=1}^{m} x_{i j}} .
$$

This formula may lead to unexpected results. Indeed, for instance in the case of productivity growth some sectors, regions or countries may show a decrease instead of an increase in productivity i.e. a negative number. In this way the sum in the denominator could become negative and ipso facto all ratios become negative. Even worse the denominator can become zero and division by zero means a senseless operation. 
Brauers, Zavadskas (2006) still tested eight other formulas. They all had main disadvantages with exception of the formula where for the denominator the square root of the sum of squares of each alternative per objective was chosen:

$$
x_{i j}^{*}=\frac{x_{i j}}{\sqrt{\sum_{j=1}^{m} x_{i j}^{2}}},
$$

with: $x_{i j}=$ response of alternative $j$ on objective $i$.

$j=1,2, \ldots, m ; m$ the number of alternatives.

$i=1,2, \ldots n ; n$ the number of objectives.

$x_{i j}^{*}=$ a dimensionless number representing the response of alternative $\mathrm{j}$ on objective $i$.

Dimensionless Numbers, having no specific unit of measurement, are obtained for instance by deduction, multiplication or division. The normalized responses of the alternatives on the objectives belong to the interval $[0 ; 1]$. However, sometimes the interval could be $[-1 ; 1]$. Indeed, for instance, in the case of productivity growth some sectors, regions or countries may show a decrease instead of an increase in productivity i.e. a negative dimensionless number.

For optimization these responses are added in case of maximization and subtracted in case of minimization:

$$
y_{j}^{*}=\sum_{i=1}^{i=g} x_{i j}^{*}-\sum_{i=g+1}^{i=n} x_{i j}^{*},
$$

with: $i=1,2, \ldots, g$ as the objectives to be maximized.

$i=g+1, g+2, \ldots, n$ as the objectives to be minimized.

$y_{j}^{*}$ as the assessment of alternative $j$ with respect to all objectives.

An ordinal ranking in a descending order of the $y_{j}^{*}$ shows the final preference.

For the second part of MOORA the Reference Point Theory is chosen with the Min-Max Metric of Tchebycheff as given by the following formula (Karlin, Studden 1966: 280):

$$
\min _{j}\left\{\max _{i}\left|r_{i}-x_{i j}^{*}\right|\right\},
$$

with $\left|r_{i}-x_{i j}^{*}\right|$ the absolute value if $x_{i j}^{*}$ is larger than $r_{i}$ for instance by minimization.

This reference point theory starts from the already normalized ratios as defined in the MOORA method, namely formula (1). Preference is given to a reference point possessing as co-ordinates the dominating co-ordinates per attribute of the candidate alternatives and which is designated as the Maximal Objective Reference Point. This approach is called realistic and non-subjective as the co-ordinates, which are selected for the reference point, are realized in one of the candidate alternatives. The alternatives A $(10 ; 100), B(100 ; 20)$ and C $(50 ; 50)$ will result in the Maximal Objective Reference Point $\mathrm{R}_{\mathrm{m}}(100 ; 100)$.

Given the composition of equation (4) the results are ranked in an ascending order. 


\subsection{The Importance given to an objective by the attribution method in MOORA}

It may look that one objective can not be much more important than another one as all their ratios are smaller than one (see formula 2) Nevertheless it may turn out to be necessary to stress that some objectives are more important than others. In order to give more importance to an objective its ratios could be multiplied with a Significance Coefficient.

In the Ratio System in order to give more importance to an objective its response on an alternative under the form of a dimensionless number could be multiplied with a Significance Coefficient:

$$
\ddot{y}_{j}^{*}=\sum_{i=1}^{i=g} s_{i} x_{i j}^{*}-\sum_{i=g+1}^{i=n} s_{i} x_{i j}^{*},
$$

with: $i=1,2, \ldots, \mathrm{g}$ as the objectives to be maximized.

$i=g+1, g+2, \ldots, n$ as the objectives to be minimized.

$s_{i}=$ the significance coefficient of objective $i$.

$\ddot{y}_{j}^{*}=$ the total assessment with significance coefficients of alternative $j$ with respect to all objectives.

For the Reference Point Approach the place of the significance coefficient would be:

$$
\min _{j}\left\{\max _{i}\left|s_{i} r_{i}-s_{i} x_{i j}^{*}\right|\right\} .
$$

The Attribution of Sub-Objectives represents another solution. Take the example of the purchase of fighter planes (Brauers 2002). For economics, the objectives concerning the fighter planes are threefold: price, employment and balance of payments, but also there is military effectiveness. In order to give more importance to military defense, effectiveness is broken down in, for instance, the maximum speed, the power of the engines and the maximum range of the plane. Anyway, the Attribution Method is more refined than a significance coefficient method could be as the attribution method succeeds in characterizing an objective better. For instance, for employment two sub-objectives replace a significance coefficient of two and in this way characterize the direct and indirect side of employment separately.

\subsection{The importance given to an objective by the attribution method in the application for the economies of the EU-countries}

After the given military example the importance given to an objective in the application for the Economies of the EU-countries is not done by the introduction of significance coefficients but by sub-objectives. However, the sub-objectives are already present but are depending on a super objective:

The Super Objective of Economic Importance represented by 10 objectives:

1. Current account deficit of the Balance of Payments (2010)

2. GDP per capita in Purchasing Power Parity (2010)

3. GDP growth rate (2010)

4. Inflation (2010) 
5. Employment rate (2010)

6. Unemployment rate (2010)

7. GDP per capita index number with basis EU-15 = 100 (2011)

8. GDP growth rate (2011)

9. GDP per capita index number with basis EU-15 = 100 (2012)

10. GDP growth rate (2011)

The Super Objective of Public Finance represented by 7 objectives:

1. Government Budget Deficit (2010)

2. Government Debt (2010)

3. Government bond yields (2010)

4. Government Budget Deficit (2011)

5. Government Debt (2011)

6. Government Budget Deficit (2012)

7. Government Debt (2012)

The Super Objective of the Population Pyramid represented by 5 objectives:

1. Tertiary education (2010)

2. Median Age (2010)

3. Proportion of population aged 0-14 (2010)

4. Proportion of population aged 15-64 (2010)

5. Proportion of population aged 65 or more (2010)

\section{MULTIMOORA}

As MOORA is based on dimensionless measures why not go further by adding the remaining form which uses dimensionless measures namely the Multiplicative Form? We even prefer to speak of the "Full-Multiplicative Form". Otherwise it could refer to a combination with linearity.

The following $n$-power form for multi-objectives is called from now on a Full-Multiplicative Form:

$$
U_{j}=\prod_{i=1}^{n} x_{i j},
$$

with: $j=1,2, \ldots, m ; m$ the number of alternatives.

$i=1,2, \ldots, n$; $n$ being the number of objectives.

$x_{i j}=$ response of alternative $j$ on objective $i$.

$U_{j}=$ overall utility of alternative $j$.

The overall utilities $\left(U_{j}\right)$, obtained by multiplication of different units of measurement, become dimensionless. The outcome of this presentation is nonlinear, which presents an advantage, as the utility function of human behavior toward several objectives has to be considered as nonlinear. 
Rule

In the full-multiplicative form the relation between the utilities $U_{j}$ does not change if more importance is given to an objective by multiplying it by a factor. Indeed, at that moment all alternatives are multiplied with that factor.

\section{Consequence 1}

In the full-multiplicative form the introduction of weights is meaningless. Indeed weights are here, in fact, multiplying coefficients.

\section{Consequence 2}

In the full-multiplicative form an attribute of the size $10,10^{2}, 10^{3}, 10^{6}, 10^{9}$ etc. can be replaced by the unit size without changing the relationship between the utilities of the alternatives.

This consequence is extremely important for attributes expressed in monetary units. Instead of expressing an attribute in tens, hundreds, thousands, millions, billions, for instance, of dollars, the use of one digit in the integer part is sufficient.

Is it possible to give more importance to an objective? Allocating an exponent to an objective signifies stressing the importance of this objective.

How is it possible to combine a minimization problem with the maximization of the other objectives? Therefore, the objectives to be minimized are denominators in the formula:

with: $A_{j}=\prod_{i=1}^{g} x_{i j}$,

$$
U_{j}^{\prime}=\frac{A_{j}}{B_{j}},
$$

$j=1,2, \ldots, m ; m$ the number of alternatives;

$i$ as the number of objectives;

$g$ as the number of objectives to be maximized;

with: $B_{j}=\prod_{i=g+1}^{n} x_{i j}$,

$n-g=$ the number of objectives to be minimized;

with: $U_{j}^{\prime}$ the utility of alternative $j$ with objectives to be maximized and objectives to be minimized.

In the Full Multiplicative Form a problem may arise for zero and negative values making the results senseless. Therefore the index number 100 replaces the zero number. At that moment for instance 96.6 substitutes the negative value of minus 3.4. Consequently, 103.4 represents the positive value of 3.4 .

Summarizing, one can conclude that the MULTIMOORA method is composed of three parts: the Ratio System, the Reference Point Method and the Full Multiplicative Form. The three methods were already discussed but separately by Brauers (2004), whereas the name of MULTIMOORA was given by Brauers and Zavadskas in 2010. 


\section{MULTIMOORA as applied on the multi-objective optimization of the economies of the EU Member countries}

The initial data were translated in dimensionless ratios according to Eqs. 2 and 3, i.e. the Ratio System of MOORA. Subsequently Eq. 4 used the ratios obtained in Eq. 2 to calculate the distances to the Reference Point of MOORA. Finally, the Full Multiplicative Form used the initial data to rank the Member States according to Eq. 6 and 7. Following Table 3 presents the results of multi-objective optimization.

Table 3. The three Approaches of MULTIMOORA as applied for the Economy of the EU Member States (a)

\begin{tabular}{|c|c|c|c|c|c|c|c|}
\hline & Member States & Ratio S. & Ref. Point & Full Multipl. F. & $\begin{array}{c}\text { Rank } \\
\text { RS }\end{array}$ & $\begin{array}{c}\text { Rank } \\
\text { RP }\end{array}$ & $\begin{array}{c}\text { Rank } \\
\text { MF }\end{array}$ \\
\hline 1 & Belgium & -0.07166 & 0.3196606 & 4182584.6 & 12 & 6 & 10 \\
\hline 2 & Bulgaria & -0.17729 & 0.5091396 & 310541.0781 & 13 & 22 & 16 \\
\hline 3 & Czech Republic & -0.11831 & 0.4534052 & 2039033.258 & 11 & 13 & 15 \\
\hline 4 & Denmark & 0.865113 & 0.2549106 & 88764673141 & 6 & 3 & 8 \\
\hline 5 & Germany & 0.373762 & 0.335337 & 65568553083 & 7 & 8 & 6 \\
\hline 6 & Estonia & 0.172228 & 0.4689265 & $1.05313 \mathrm{E}+12$ & 4 & 16 & 2 \\
\hline 7 & Ireland & -0.50645 & 0.7270675 & 12751986265 & 25 & 26 & 23 \\
\hline 8 & Greece & -1.1709 & 0.710736 & 68949.84482 & 27 & 27 & 27 \\
\hline 9 & Spain & -0.38842 & 0.4814092 & 582713.4039 & 24 & 19 & 25 \\
\hline 10 & France & 0.11367 & 0.3719685 & 18481324.78 & 18 & 9 & 18 \\
\hline 11 & Italy & -0.33378 & 0.4322718 & 3849003.582 & 22 & 12 & 22 \\
\hline 12 & Cyprus & -0.0528 & 0.6053159 & 3072201.537 & 19 & 24 & 20 \\
\hline 13 & Latvia & -0.3024 & 0.4873291 & $9.29662 \mathrm{E}+11$ & 15 & 21 & 12 \\
\hline 14 & Lithuania & -0.16221 & 0.4846028 & 1715231781 & 10 & 20 & 11 \\
\hline 15 & Luxemburg & 1.609567 & 0.5091396 & $1.45714 \mathrm{E}+11$ & 1 & 7 & 3 \\
\hline 16 & Hungary & -0.26461 & 0.4757423 & 1046439986 & 20 & 17 & 5 \\
\hline 17 & Malta & -0.21317 & 0.466408 & 2143188.821 & 17 & 15 & 17 \\
\hline 18 & Netherlands & 0.75226 & 0.3005764 & $1.9199 \mathrm{E}+11$ & 5 & 2 & 7 \\
\hline 19 & Austria & 0.378763 & 0.3094369 & 49788752164 & 8 & 4 & 9 \\
\hline 20 & Poland & -0.33806 & 0.4784686 & 419639.2501 & 16 & 18 & 19 \\
\hline 21 & Portugal & -0.83554 & 0.6884153 & 256512.0942 & 26 & 25 & 26 \\
\hline 22 & Romania & -0.38694 & 0.5030054 & 42127.3994 & 23 & 23 & 24 \\
\hline 23 & Slovenia & 0.054059 & 0.4239422 & 7002669.453 & 14 & 10 & 14 \\
\hline 24 & Slovakia & -0.29411 & 0.4593844 & 1376975.646 & 9 & 14 & 13 \\
\hline 25 & Finland & 0.567699 & 0.3128448 & 70281186108 & 3 & 5 & 4 \\
\hline 26 & Sweden & 1.716535 & 0.2896712 & $1.53242 \mathrm{E}+14$ & 2 & 1 & 1 \\
\hline 27 & United Kingdom & -0.00365 & 0.427989 & 4160130.904 & 21 & 11 & 21 \\
\hline
\end{tabular}

(a) The details of the calculations can eventually be given by the authors. Table 2 forms the basis of these calculations. 


\section{The theory of dominance}

How to make a synthesis between the results of the three approaches: Ratio System, Reference Point Method, which uses the ratios obtained in the ratio system as coordinates, and the Full Multiplicative Form?

The use of the Rank Correlation Method is misleading, see Appendix A. Instead Brauers et al. developed a Theory of Dominance (Brauers, Zavadskas 2011).

\subsection{Axioms on ordinal and cardinal scales}

1. A deduction of an Ordinal Scale, a ranking, from cardinal data is always possible (Arrow 1974).

2. An Ordinal Scale can never produce a series of cardinal numbers (Arrow).

3. An Ordinal Scale of a certain kind, a ranking, can be translated in an ordinal scale of another kind.

In application of axiom 3 we shall translate the ordinal scales of the three methods of MULTIMOORA in another one based on Dominance, being Dominated, Transitivity and Equability.

\subsection{Dominance, being dominated, transitiveness and equability}

Stakeholders or their representatives may give a different importance to objectives in a multiobjective problem, but this is not the case with the three methods of MULTIMOORA. These three methods represent all possible methods with dimensionless measures in multi-objective optimization and one can not argue that one method is better than or is of more important than the other ones.

\section{Dominance}

Absolute Dominance means that an alternative, solution or project is dominating in ranking all other alternatives, solutions or projects which are all being dominated. This absolute dominance shows as rankings for MULTIMOORA: (1-1-1).

General Dominance in two of the three methods with a P b P c P d ( $\mathrm{P}$ preferred to) is for instance of the form:

$(d-a-a)$ is generally dominating (c-b-b).

(a-d-a) is generally dominating (b-c-b).

(a-a-d) is generally dominating (b-b-c)

and further on transitiveness plays fully.

\section{Transitiveness}

If $\mathrm{a}$ dominates $\mathrm{b}$ and $\mathrm{b}$ dominates $\mathrm{c}$ than a will also dominate $\mathrm{c}$.

Overall Dominance of one alternative on another

For instance (a-a-a) is overall dominating (b-b-b) which is being overly dominated by (a-a-a).

Equability

Absolute Equability has the form: for instance (e-e-e) for 2 alternatives.

Partial Equability of 2 on 3 exists e. g. (5-e-7) and (6-e-3). 


\section{Circular Reasoning}

Despite all distinctions in classification some contradictions remain possible in a kind of Circular Reasoning.

We can cite the case of:

Object A (11-20-14) dominates generally Object B (14-16-15).

Object B (14-16-15) dominates generally Object C (15-19-12)

but Object C (15-19-12) dominates generally Object A (11-20-14).

In such a case the same ranking is given to the three objects.

The same rules apply for the three methods of MULTIMOORA with no significance coefficients proposed as the three methods are considered to have the same importance.

In the following Table 4 the final classification of MULTIMOORA is presented.

Table 4. The final classification of MULTIMOORA for the Economies of the EU Countries

\begin{tabular}{|c|c|c|c|c|}
\hline MULTIMOORA & Countries & Rank RS & Rank RP & Rank MF \\
\hline 1 & Sweden & 2 & 1 & 1 \\
\hline 2 & Luxemburg & 1 & 7 & 3 \\
\hline 3 & Finland & 3 & 5 & 4 \\
\hline 4 & Netherlands & 5 & 2 & 7 \\
\hline 5 & Denmark & 6 & 3 & 8 \\
\hline 6 & Germany & 7 & 8 & 6 \\
\hline 7 & Austria & 8 & 4 & 9 \\
\hline 8 & Estonia & 4 & 16 & 2 \\
\hline 9 & Belgium & 12 & 6 & 10 \\
\hline 10 & Slovakia & 9 & 14 & 13 \\
\hline 11 & Slovenia & 14 & 10 & 14 \\
\hline 12 & Lithuania & 10 & 20 & 11 \\
\hline 13 & Czech Republic & 11 & 13 & 15 \\
\hline 14 & France & 18 & 9 & 18 \\
\hline 15 & Hungary & 20 & 17 & 5 \\
\hline 16 & Latvia & 15 & 21 & 12 \\
\hline 17 & Malta & 17 & 15 & 17 \\
\hline 18 & Bulgaria & 13 & 22 & 16 \\
\hline 19 & Poland & 16 & 18 & 19 \\
\hline 20 & Cyprus & 19 & 24 & 20 \\
\hline 21 & U. K. & 21 & 11 & 21 \\
\hline 22 & Italy & 22 & 12 & 22 \\
\hline 23 & Romania & 23 & 23 & 24 \\
\hline 24 & Spain & 24 & 19 & 25 \\
\hline 25 & Ireland & 25 & 26 & 23 \\
\hline 26 & Portugal & 26 & 25 & 26 \\
\hline 27 & Greece & 27 & 27 & 27 \\
\hline
\end{tabular}

If there is General Dominance in two of the three methods the domination is indicated with a large bold figure. 


\subsection{Some special remarks}

Overall Dominance of one Alternative on another is noted in the following cases:

- The Netherlands on Denmark

- Poland on Cyprus

- United Kingdom on Italy and Romania

- Italy on Romania

- Portugal on Greece.

The group of ten which only joined the EU in 2004 is doing quite well and especially these countries: Estonia (which even joined the EURO Group), Slovakia, Slovenia, Lithuania, and the Czech Republic.

The so called PIIGS are indeed the last classified together with Romania, but also the United Kingdom is not very well classified.

\section{Conclusion}

We prefer to estimate the economic worth of the European Union Member States by MultiObjective Optimization towards 2020. Therefore 22 objectives with an actual and future outlook were selected to characterize each EU Member State.

Next problem was the choice of an effective method of Multi-Objective Optimization. This method has to use complete and not partial aggregation, as an overall view of the countries is needed, and has to avoid the use of weights, being dual on normalization and importance. Therefore methods based on dimensionless measures are preferred. Responding to all these conditions MULTIMOORA was finally chosen. In addition MULTIMOORA is composed of three approaches, each controlling each other. In this way all possible methods based on dimensionless measures are included.

Having the results of the three approaches, Ratio Analysis System, Reference Point Approach and Full Multiplicative Form, the problem remains how to come to a final and unique solution. For that purpose the correlation of ranks is senseless. A Theory of Dominance is rather preferred.

The final results classify Sweden, first followed by Luxemburg, Finland, the Netherlands and Denmark. Some of the ten countries, which joined the EU in 2004, are doing quite well, leaded by Estonia, which even joined the EMU. As expected the PIIGS countries are classified at the bottom, but joined by an unforeseen United Kingdom. In this way we have an idea how the European countries are advancing on economic terms to the European Strategy for 2020.

On basis of the outcomes it would perhaps be possible, eventually with more available data, to come to ratings comparable to the Credit Rating Agencies ratings. Further investigation in this sense could be useful.

\section{References}

Afonso, A.; Gomes, P.; Rother, P. 2011. Short and long-run determinants of sovereign debt credit ratings, International Journal of Finance and Economics 16: 1-15. http://dx.doi.org/10.1002/ijfe.416

Arrow, K. J. 1974. General economic equilibrium: purpose, analytic techniques, collective choice, American Economic Review (June): 253-272. 
Belgian Federal Department of Finance 2008. Documentatieblad 68, No.1.

Brans, J. P.; Mareschal, B.; Vincke, P. 1984. Prométhée: a new family of outranking methods in multicriteria analysis, in Brans, J. P. (Ed.). Proceedings of the IFORS 84 Conference. Washington, 408-421.

Brauers, W. K. 2004. Optimization Methods for a Stakeholder Society, a Revolution in Economic Thinking by Multi-Objective Optimization. Series: Nonconvex Optimization and its Applications, Vol. 73. Kluwer Academic Publishers and Springer, Boston-Dordrecht-London. 342 p. ISBN 1-4020-7681-9.

Brauers, W. K. 2002. The multiplicative representation for multiple objectives optimization with an application for arms procurement, Naval Research Logistics, Wiley Periodicals 49: 327-340. http://dx.doi.org/10.1002/nav.10014

Brauers, W. K. M.; Ginevičius, R. 2010. The economy of the Belgian regions tested with MULTIMOORA, Journal of Business Economics and Management 11(2): 173-209.

http://dx.doi.org/10.3846/jbem.2010.109

Brauers, W. K.; Zavadskas, E. K. 2011. MULTIMOORA optimization used to decide on a bank loan to buy property, Technological and Economic Development of Economy 17(1): 174-188. http://dx.doi.org/10.3846/13928619.2011.560632

Brauers, W. K.; Zavadskas, E. K. 2010. Project Management by MULTIMOORA as an instrument for transition economies, Technological and Economic Development of Economy 16(1): 5-24. http://dx.doi.org/10.3846/tede.2010.01

Brauers, W. K.; Zavadskas, E. K. 2006. The MOORA method and its application to privatization in a transition economy, Control and Cybernetics 35(2): 443-468.

Chakraborty, S. 2011. Applications of the MOORA method for decision making in manufacturing environment, International Journal of Advanced Manufacturing Technology 54: 1155-1166. http://dx.doi.org/10.1007/s00170-010-2972-0

Churchman, C. W.; Ackoff, R. L.; Arnoff, E. L. 1957. Introduction to Operations Research. New York: Wiley. http://dx.doi.org/10.2307/3029173

Churchman, C. W.; Ackoff, R. L. 1954. An approximate measure of value, Operations Research 2: 172-180. http://dx.doi.org/10.1287/opre.2.2.172

Condorcet, Marquis de. 1785. Essai sur l’application de l'analyse à la probabilité des décisions rendues à la pluralité des voix. Paris, l'Imprimerie royale.

Despontin, M.; Moscarola, J.; Spronk, J. 1983. A user-oriented listing of multiple criteria decision methods, Revue Belge de Statistique, d'Informatique et de Recherche Operationnelle 23: 4.

European Central Bank. 2011. Statistical Data Warehouse (SDW) [cited 17 November 2011]. Available from Internet: http://sdw.ecb.europa.eu.

European Commission. 2011. Statistical Annex of European Economy. Spring 2011.

European Commission. 2010. Communication from the Commission: Europe 2020. A Strategy for smart, sustainable and inclusive growth. 3.3.2010, $\operatorname{COM}(2010) 2020$.

European Council. 2000. Presidency Conclusions. Lisbon, 23 and 24 March, SN100/00.

EUROSTAT. 2011 [cited 17 November 2011]. Available from Internet: http://epp.eurostat.ec.europa.eu/ portal/page/portal/statistics/search_database.

Fouladgar, M. M.; Yazdani-Chamzini, A.; Zavadskas, E. K.; Yakhchali, S. H.; Ghasempourabadi, M. H. 2012. Project portfolio selection using fuzzy AHP and VIKOR techniques, Transformations in Business \& Economics 11(1): 213-231.

Gagnon, J. E. 2011. The Global Outlook for Government Debt over the next 25 years; Implications for the Economy and Public Policy. Peterson Institute for International Economics. Vol. 34. Washington D.C.

Gossen, H. H. 1853. Entwicklung der Gesetze des menschlichen Verkehrs und der daraus flieszenden Regeln für menschliches Handeln. 3 Auflage, Prager, Berlin, 1927. 
Hwang, C.-L.; Yoon, K. 1981. Multiple Attribute Decision Making, Methods and Applications. Lecture Notes in Economics and Mathematical Systems, Berlin: Springer. 186.

http://dx.doi.org/10.1007/978-3-642-48318-9

International Monetary Fund. 2011. World Economic Outlook Database. Washington, D.C. [cited 17 December 2011] Available from Internet: http://www.imf.org/external/pubs/ft/weo/2011/01/weodata/index.aspx.

Karlin, S.; Studden, W. J. 1966. Tchebycheff Systems: with Applications in Analysis and Statistics. Interscience Publishers, New York. http://dx.doi.org/10.1214/aoms/1177699361

Kendall, M. G.; Gibbons, J. D. 1990. Rank Correlation Methods. London, Edward Arnold.

Kendall, M. G. 1948. Rank Correlation Methods. Griffin, London.

Lootsma, F. A. 1987. Numerical Scaling of Human Judgement in Pairwise-comparison Methods for Fuzzy Multi-criteria Decision Analysis, in NATO Advanced Study Institute, Val d'Isere (F), July 1987, Thu 39.

MacCrimmon, K. R. 1968. Decision Making among Multiple Attribute Alternatives. A Survey and Consolidated Approach. RM-4823-ARPA, CAL, Santa Monica: the Rand Corporation.

Miller, D. W.; Starr, M. K. 1969. Executive Decisions and Operations Research. 2nd edition. N.J., Englewood Cliffs: Prentice-Hall Inc.

Miller, G. A. 1965. The magical number seven plus or minus two: some limits on our capacity for processing information, Psychological Review 63: 81-97. http://dx.doi.org/10.1037/h0043158

Minkowsky, H. 1896. Geometrie der Zahlen. Teubner, Leipzig.

Minkowsky, H. 1911. Gesammelte Abhandlungen. Teubner, Leipzig.

Opricovic, S.; Tzeng, G.-H. 2004. Compromise solution by MCDM methods: a comparative analysis of VIKOR and TOPSIS, EJOR 156: 445-455. http://dx.doi.org/10.1016/S0377-2217(03)00020-1

Pareto, V. 1906. Manuale di Economia Politica. Translation revised by Pareto Himself: Manuel déconomie politique. 2nd ed. Paris, 1927.

Roy, B.; Benayoun, R.; Sussman, B. 1966. ELECTRE. Société d’economie et de Mathématique appliquées, Paris.

Saaty, T. L. 1988. The Analytic Hierarchy Process. New York: Mcgraw-Hill.

Saaty, T. L. 1987. What is the Analytic Hierarchy Process?, in Mathematical Models for Decision Support, Nato Advanced Study Institute, Val d'Isere (F), July 26, 1987, Mon 82.

Schärlig, A. 1996. Pratiquer Electre et Prométhée. Presses polytechniques et universitaires romandes, Lausanne.

Schärlig, A. 1985. Décider sur plusieurs critères. Presses polytechniques romandes, Lausanne.

Spearman, C. 1904. The proof and measurement of association between two things, American Journal of Psychology 15: 72-101. http://dx.doi.org/10.2307/1412159

Spearman, C. 1906. A footrule for measuring correlation, British Journal of Psychology 2: 89-108. http://dx.doi.org/10.1111/j.2044-8295.1906.tb00174.x

Spearman, C. 1910. Correlation calculated from faulty data, British Journal of Psychology 3: 271-295. http://dx.doi.org/10.1111/j.2044-8295.1910.tb00206.x

World Bank 2011. World Development Indicators Database. [cited 17 December 2011]. Available from Internet: http://data.worldbank.org/data-catalog/world-development-indicators. 


\section{APPENDIX A}

\section{The rank correlation method}

The method of correlation of ranks consists of totalizing ranks. Rank correlation was introduced first by psychologists such as Spearman (1904, 1906 and 1910) and later taken over by the statistician Kendall in 1948. He argues (Kendall 1948: 1): "we shall often operate with these numbers as if they were the cardinals of ordinary arithmetic, adding them, subtracting them and even multiplying them," but he never gives a proof of this statement. In his later work this statement is dropped (Kendall and Gibbons 1990).

In ordinal ranking 3 is farther away from 1 than 2 from 1, but Kendal (1948: 1) goes too far (Table A1).

For Kendal B is far away from $\mathrm{A}$ as it has 7 ranks before and A only 4 , whereas it is not true cardinally.

In addition a supplemental notion, the statistical term of Correlation, is introduced. Suppose the statistical universe is just represented by two experts, for us it could be two methods. If they both rank different items in a same order to reach a certain goal, it is said that the correlation is perfect. However, perfect correlation is a rather exceptional situation. The problem is then posited: how is correlation measured in other situations. Therefore, the following Spearman's coefficient is used (Kendall 1948: 8):

$$
\rho=1-\frac{6 \sum D^{2}}{N\left(N^{2}-1\right)},
$$

where $D$ stands for the difference between paired ranks, and $N$ for the number of items ranked.

According to this formula, perfect correlation yields the coefficient of one. An acceptable correlation reaches the coefficient of one as much as possible. No correlation at all yields a coefficient of zero. If the series are exactly in reverse order, there will be a negative correlation of minus one, as shown in the following example (Table A2).

Table A1. Ordinal versus cardinal: comparing the price of one commodityl

\begin{tabular}{ccc}
\hline & Ordinal & Cardinal \\
\hline & 1 & \\
\hline & 2 & \\
\hline & 3 & \\
\hline $\mathrm{A}$ & 4 & $6.03 \$$ \\
\hline & 5 & $6.02 \$$ \\
\hline $\mathrm{B}$ & 6 & $6.01 \$$ \\
\hline
\end{tabular}

Table A2. Negative rank order correlations

\begin{tabular}{ccccc}
\hline Items & Expert 1 & Expert 2 & $\mathrm{D}$ & $\mathrm{D}^{2}$ \\
\hline 1 & 1 & 7 & -6 & 36 \\
\hline 2 & 2 & 6 & -4 & 16 \\
\hline 3 & 3 & 5 & -2 & 4 \\
\hline 4 & 4 & 4 & 0 & 0 \\
\hline 5 & 5 & 3 & 2 & 4 \\
\hline 6 & 6 & 2 & 4 & 16 \\
\hline 7 & 7 & 1 & 6 & 36 \\
\hline & & & & - \\
\hline$\sum$ & & & & 112 \\
\hline
\end{tabular}


This table shows that the sum of ranks in the case of an ordinal scale has no sense. Correlation leads to:

$$
\rho=1-\frac{6 \times 112}{7(49-1)}=-1 \text {. }
$$

However, as addition of ranks is not allowed, also a subtraction, the difference D, is not permitted, nor the multiplication or the division.

Most people will understand the ordinal problem better by the way of a qualitative scale, e. g.:

$1^{\text {st }}$ very good;

$2^{\text {nd }}$ moderate;

$3^{\text {rd }}$ very bad.

But equally one could say:

$1^{\text {st }}$ very good;

$2^{\text {nd }}$ good;

$3^{\text {rd }}$ more or less good;

$4^{\text {th }}$ moderate;

$5^{\text {th }}$ more or less low;

$6^{\text {th }}$ low;

$7^{\text {th }}$ very low.

How is the first $2^{\text {nd }}$ comparable with the second $2^{\text {nd? }}$ etc.

Arbitrary Methods to go from an Ordinal Scale to a Cardinal Scale

1) Arithmetical Progression: 1, 2, 3, 4, 5.........

2) A Geometric Progression: 1, 2, 4, 8, 16.........

3) The Fundamental Scale of Saaty (1987): 1, 3, 5, 7, 9

4) The Normal Scale of Lootsma (1987)

$\mathrm{e}^{\circ}=1$

$\mathrm{e}^{1}=2.7$

$\mathrm{e}^{2}=7.4$

$\mathrm{e}^{3}=20.1$

5) The Stretched Scale of Lootsma (1987)

$\mathrm{e}^{\mathrm{o}}=1$

$\mathrm{e}^{2}=7.4$

$\mathrm{e}^{4}=54.6$

$\mathrm{e}^{6}=403.4 \ldots \ldots \ldots$

6) The Point of View of the Psychologists (Miller 1965)

Ordinal Scales: 1, 2, 3, 4, 5, 6, 7.

After 7 an individual would no more know the cardinal significance compared to the previous 7 ones.

In fact infinite variations are possible. They all stress acceleration or dis-acceleration processes but are not aware of a possible trend break. The full multiplicative method with its huge numbers illustrates this trend break the best as shown in next Table A3.

With the usual Arithmetical Progression: $1,2,3,4,5, \ldots$ the distance from the rank 4 to 5 would be the same as from 3 to 4 which is certainly not the case here. In addition, all the other progressions fail to discover a trend break too. 
Table A3. Ranking of scenarios for the Belgian regions by the Full-Multiplicative Method at the year 1996

\begin{tabular}{cclc}
\hline 1 & Scenario IX & Optimal Economic Policy in Wallonia and Brussels & 203,267 \\
\hline 2 & Scenario X & $\begin{array}{l}\text { Optimal Economic Policy in Wallonia and Brussels even agreeing on } \\
\text { the Partition of the National Public Debt }\end{array}$ & 196,306 \\
\hline 3 & Scenario VII & Flanders asks for the Partition of the National Public Debt & 164,515 \\
\hline 4 & Scenario VIII & No Solidarity at all & 158,881 \\
\hline 5 & Scenario II & Unfavorable Growth Rate for Flanders & 90 \\
\hline 6 & Scenario IV & $\begin{array}{l}\text { an Unfavorable Growth Rate for Flanders and at that moment asks } \\
\text { also for the Partition of the National Public Debt }\end{array}$ & 87 \\
\hline 7 & Scenario III & Partition of the National Public Debt & 54 \\
\hline 8 & Scenario I & the Average Belgian & 51 \\
\hline 9 & Scenario V & $\begin{array}{l}\text { Average Belgian but as compensation Flanders asks for the Partition } \\
\text { of the National Public Debt }\end{array}$ & 49 \\
\hline 10 & Scenario O & Status Quo & 43 \\
\hline 11 & Scenario VI & Flanders asks for the Partition of the National Public Debt & 42 \\
\hline
\end{tabular}

Source: Brauers, Ginevičius (2010)

Willem K. M. BRAUERS. Doctor honoris causa Vilnius Gediminas Technical University, was graduated as: Ph.D. in economics (Un. of Leuven), Master of Arts (in economics) of Columbia Un. (New York), Master in Economics, Master in Management and Financial Sciences, Master in Political and Diplomatic Sciences and Bachelor in Philosophy (all of the Un. of Leuven). He is professor ordinarius at the Faculty of Applied Economics of the University of Antwerp, Honorary Professor at the University of Leuven, the Belgian War College, the School of Military Administrators and the Antwerp Business School. He was a research fellow in several American institutions like Rand Corporation, the Institute for the Future, the Futures Group and extraordinary advisor to the Center for Economic Studies of the University of Leuven. He was consultant in the public sector, such as the Belgian Department of National Defense, the Department of Industry in Thailand, the project for the construction of a new port in Algeria (the port of Arzew) and in the private sector such as the international seaport of Antwerp and in electrical works. He was Chairman of the Board of Directors of SORCA Ltd. Brussels, Management Consultants for Developing Countries, linked to the worldwide group of ARCADIS and Chairman of the Board of Directors of MARESCO Ltd. Antwerp, Marketing Consultants. At the moment he is General Manager of CONSULTING, Systems Engineering Consultants. Brauers is member of many international scientific organizations. His specialization covers: Optimizing Techniques with Different Objectives, Forecasting Techniques, Input-Output Techniques and Public Sector Economics such as for National Defense and for Regional Sub-optimization. His scientific publications consist of seventeen books and several hundreds of articles and reports in English, Deutch and French.

Alvydas BALEŽENTIS. PhD (HP) in management and administration, is Professor at the Department of Strategic Management in Mykolas Romeris University. While working at the Parliament of the Republic of Lithuania, Ministry of Agriculture, and Institute of Agrarian Economics he contributed to creation and fostering of the Lithuanian rural development policy at various levels. His scientific interests cover areas of innovatics, strategic management, sustainable development and rural development.

Tomas BALEŽENTIS is specialist at the Lithuanian Institute of Agrarian Economics. His working experience includes traineeship at the European Parliament and working at the Training Centre of the Ministry of Finance. His scientific interests: quantitative methods in social sciences, multi-criteria decision making, fuzzy logics, benchmarking methods. 